\title{
Assessment of the ecological functionality of anthropogenically created habitats in the impoundment of the hydropower plant Freudenau (Vienna, Austria) with bi- and multivariate statistical analyses
}

\author{
Martin Tarkus"; Christian Volkmann1; Silke-Silvia Drexler²; Herwig Waidbacher² \& Michael Straif² \\ 1 Postgraduate program of Applied Hydrobiology and Bioengeneering, Institute of Hydrobiology and Aquatic Ecosystem \\ Management, University of Natural Resources and Applied Life Sciences, Vienna. Max - Emanuel-Strasse 17, 1180 Wien, \\ Austria. E-mail: martin.tarkus@gmail.com; utgard@gmx.at \\ ${ }^{2}$ Institute of Hydrobiology and Aquatic Ecosystem Management, University of Natural Resources and Applied Life Sciences, \\ Vienna. Max - Emanuel-Strasse 17, 1180 Wien, Austria. E-mail: silke.drexler@boku.ac.at; herwig.waidbacher@boku.ac.at; \\ mstraif@spss.com
}

\begin{abstract}
The construction of the hydropower plant Freudenau was accompanied by the introduction of new structures and habitats. This study processes and evaluates the ecological fish data for the periods 1999/2000 and 2003/ 2004. The area was subdivided into five sections and 19 habitats (stream kilometer 1914.50 to 1994.60). Bi- and multivariate analyses were inducted with SPSS ${ }^{\odot}$ (SPSS 2007). The CPUE values show that most fish remain in the Transition Zone and in the Head of Reservoir. The cluster analyses of the individual habitats show that these can be characterized primarily by abiotic factors. There was a strong statistical relationship between the individual habitats and the Danube mainstream. We conclude that fish have access to the habitats and that there is interconnectivity between these habitats. In general, the habitats were highly accepted by the fish species: all contained both juvenile and adult fish. The differentiated spectrum of species points to complex relationships. In principle the newly created habitats can be considered to be good replacement environments.
\end{abstract}

KEY WORDS. Aquatic ecosystems; fish ecology; hydraulic engineering; river management.

In potamal rivers, hydropower plants represent special ecological problems. The low descent requires large-dimensioned impoundments. Monotonous habitats arise both in the retention areas and tailwaters. Hinterland detachment and groundwater isolation impair the riparian forest. Key features include the reduction of dynamic processes, such as one-sided directional developments, which are expressed as degradation and obsolescence of the vegetation. The river bed erosion related to bed load retention represents another problem (JUNGWIRTH et al. 2003).

Originally, the Danube in the Vienna area was a braided river system with numerous mainstreams and tributaries. The regulation in the $19^{\text {th }}$ century, however, created a single river mainstream. The typical fish fauna is therefore confined to the main arm of the river. The regulation increased flow velocity and river bed erosion, leading to a dominance of rheophilic fish species (WAIDBACHer et al. 1996).

During the construction of the hydropower plant Freudenau, structures and habitats were created and a bypass channel was built according to the requirements of the European Water Framework Directive. This was preceded by research by the Institute of Hydrobiology and Aquatic Water Management, University for Natural Resources and Applied Life Sciences, into the ecological preservation in the area of hydropower plant Freudenau (WAIDBACHER et al. 1996).

Both benthic long-term relationships and the fish biocenosis were studied. The study focused on the fish ecological conditions. Due to their various ecological requirements, fish species are excellent indicators for hydromorphological changes; this is decisive in assessing the freshwater ecology and especially the ecological functionality. Accordingly, fish are crucial indicators for continuum conditions and for habitat structures (Schmutz et al. 2000).

The ecological functionality is the ability to maintain the ecological integrity between waters and the occurrence of organisms in the surrounding area, according to the natural characteristics of the respective water body type (АDміскA et al. 1992).

This study evaluates the fish ecological functionality of anthropogenic shore structures related to the temporal gradient at the hydropower plant Freudenau. 


\section{MATERIAL AND METHODS}

The hydropower plant Freudenau, built between 1992 and 1998, was the first large, modern power plant ever built in a major city. For a detailed investigation, the study area (stream kilometer 1914.50 to 1994.60) was divided into five sections (GINZLER 2002). Each section contains various habitat structures located on the left river side. The five river sections are: Tailwater (strkm. 1914.50 to 1921.05), Impoundment (strkm. 1921.05 to 1928.00), Transition Zone (strkm. 1928.00 to 1935.00), Head of Reservoir (strkm. 1935.00 to 1945.50) and Free Flowing Stretches (strkm. 1945.50) (Fig. 1).

During the construction of the power plant, nine artificial habitats (A-I) were installed on the left river bank to simulate tributaries and bays. Habitat A (strkm. 1921.90 to strkm. 1922.40), B (strkm. 1923.90 to strkm. 1924.50), C (strkm. 1926.20 to strkm. 1926.70) and D (strkm. 1927.35 to strkm. 1927.50) are situated in the Impoundment. The Transition Zone encompasses habitats E (strkm. 1928.80 to strkm. 1928.90), F (strkm. 1929.90 to strkm. 1930.10) and G (strkm. 1930.90 to strkm. 1931.10). The Head of Reservoir is characterized by the habitat H (strkm. 1932.20 to strkm. 1932.50) and I (strkm. 1934.80 to strkm. 1935.50).
E-fishing creates an electric, externally applied DC field in the water to which fish react. Individuals in the electric field lines actively swim to the anode and are narcotized (electrotype narcosis). The efficiency and domain of this method depend on the conductivity of the water. E-fishing is a quantitative and species-selective fishing technique (Cowx \& LAMARQUE 1990).

The captured fish were determined on the spot, measured and weighed. Those individuals that could not be determined (primarily juveniles) were fixed in a $4 \%$ formalin solution and later examined under a stereomicroscope. In most cases the sampling unit of the "CPUE" (Catch Per Unit Effort) was determined by the number of individuals per ten minutes of fishing.

The fish ecological data from 1999 to 2000 as well as from 2003 to 2004 were processed, evaluated and analyzed with multivariate statistical methods.

The data collected formed the Access databases "Freudenau" (1999/2000) and "FIDON" (2003/2004) of the Institute for Hydrobiology and Aquatic Ecosystem Management. They were further subjected to bi- and multivariate analyses and their temporal course evaluated. The E-fishing data were used to obtain values for an efficient statistical evaluation with binary data, frequencies and "Catch Per Unit Effort" (CPUE). SPSS 16.0 was used for the bi- and multivariate analyses.

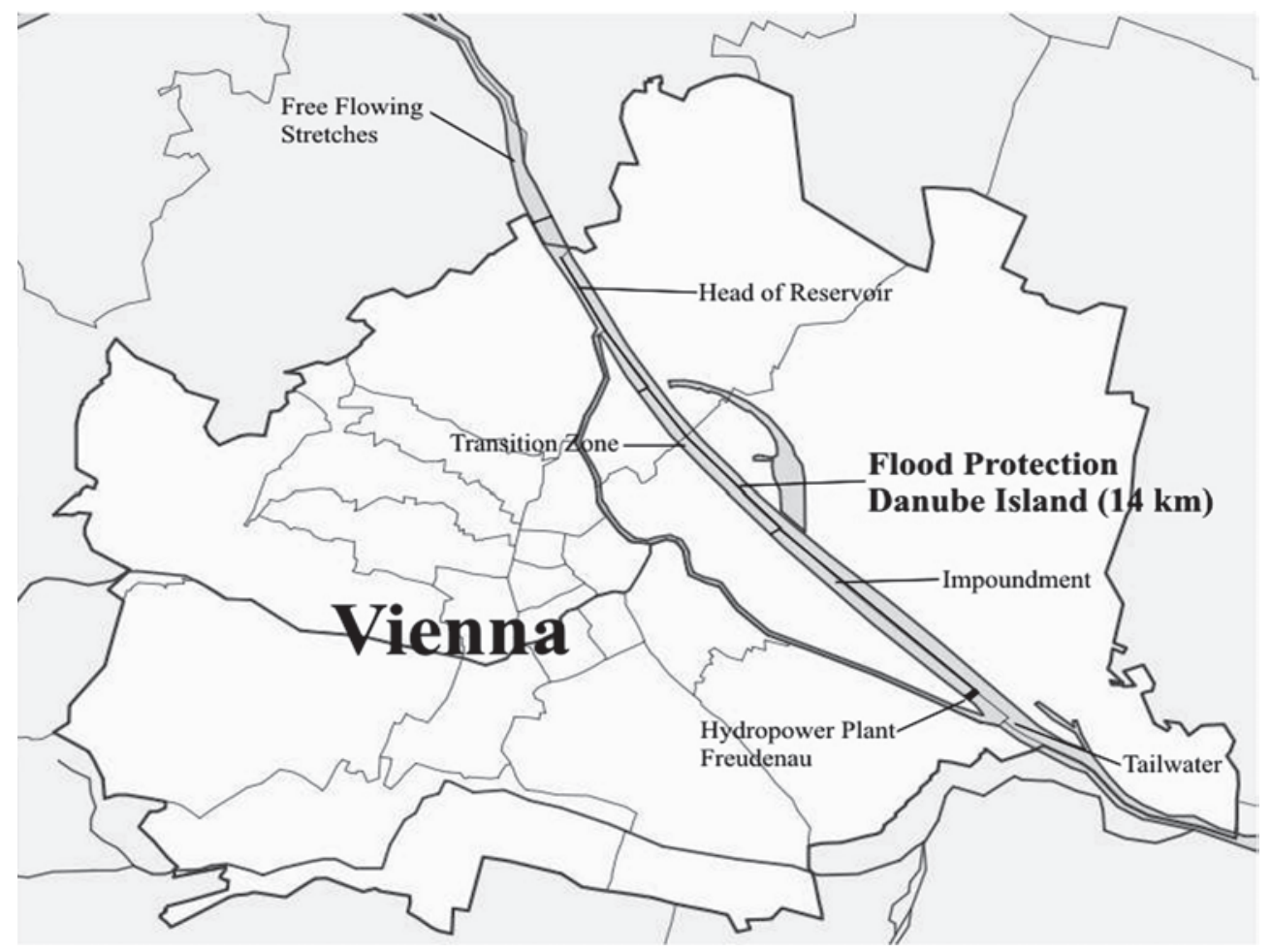

Figure 1. Map of the investigation area including the five sections Tailwater, Impoundment, Transition Zone, Head of Reservoir and Free Flowing Stretches. 
Hierarchical cluster analyses were conducted. The Ward method was used as a cluster method and the squared euclidean distance was chosen as a measure of the standard interval. Discriminant analysis was used to check the clusters.

After the cluster analyses, the mean average values of the frequencies and binary data of the fish were compared with each other to visualize the arrangement of the fish species in the partial clusters

The formation of rankings enabled an optimal comparison, which was illustrated graphically with regard to the frequencies of the juvenile and adult fish. The rank variance analysis was carried out using the Friedman test; the coefficient of concordance was calculated with the Kendall-W test.

\section{RESULTS}

From April 1999 to November 2000 and from July 2003 to October 2004, a total of 24,680 individuals of 52 species were caught by E-fishing in the study area (Tab. I). The most frequent species were Bleak, Alburnus alburnus (Linnaeus, 1758); Nase, Chondrostoma nasus (Linnaeus, 1758); and Roach, Rutilus rutilus (Linnaeus, 1758). The rarest species were Mediterranean Barbel, Barbus peloponnesius Valenciennes, 1842; Stone Loach, Barbatula barbatula (Linnaeus, 1758); and Spirlin, Alburnoides bipunctatus (Bloch, 1782).

Most fish were caught in the Transition Zone and Head of Reservoir (Fig. 2), the fewest in the Free Flowing Stretches.

Table I. Fish frequencies at the study site, Danube River, Vienna, Austria.

\begin{tabular}{|c|c|c|c|}
\hline Species & Frequency & Species & Frequency \\
\hline Barbus peloponnesius & 1 & Cobitis taenia & 80 \\
\hline Neogobius syrman & 1 & Cyprinus carpio & 88 \\
\hline Barbatula barbatula & 2 & Carassius gibelio & 94 \\
\hline Carassius carassius & 2 & Tinca tinca & 94 \\
\hline Alburnoides bipunctatus & 2 & Sander lucioperca & 111 \\
\hline Abramis ballerus & 2 & Neogobius melanostomus & 138 \\
\hline Gobio gobio & 3 & Gymnocephalus schraetser & 141 \\
\hline Hucho hucho & 3 & Rutilus pigus virgo & 142 \\
\hline Anguilla anguilla & 4 & Lota lota & 179 \\
\hline Lepomis gibbosus & 4 & Vimba vimba & 220 \\
\hline Silurus glanis & 4 & Abramis brama & 261 \\
\hline Ctenopharyngodon idella & 5 & Cottus gobio & 285 \\
\hline Zingel streber & 5 & Blicca bjoerkna & 291 \\
\hline Ameiurus nebulosus & 5 & Esox lucius & 307 \\
\hline Abramis sapa & 7 & Neogobius kessleri & 387 \\
\hline Oncorhynchus mykiss & 8 & Proterorhinus marmoratus & 402 \\
\hline Salmo trutta f.f. & 10 & Gasterosteus aculeatus & 513 \\
\hline Carassius auratus & 11 & Leuciscus leuciscus & 513 \\
\hline Gobio kessleri & 12 & Aspius aspius & 606 \\
\hline Pelecus cultratus & 13 & Barbus barbus & 746 \\
\hline Gymnocephalus cernuus & 24 & Leuciscus idus & 1062 \\
\hline Gobio albipinnatus & 24 & Perca fluviatilis & 1218 \\
\hline Gymnocephalus baloni & 44 & Leuciscus cephalus & 1542 \\
\hline Scardinius erythrophthalmus & 55 & Rutilus rutilus & 3259 \\
\hline Zingel zingel & 69 & Chondrostoma nasus & 4151 \\
\hline Rhodeus sericeus & 77 & Alburnus alburnus & 7453 \\
\hline Total & & & 24680 \\
\hline
\end{tabular}




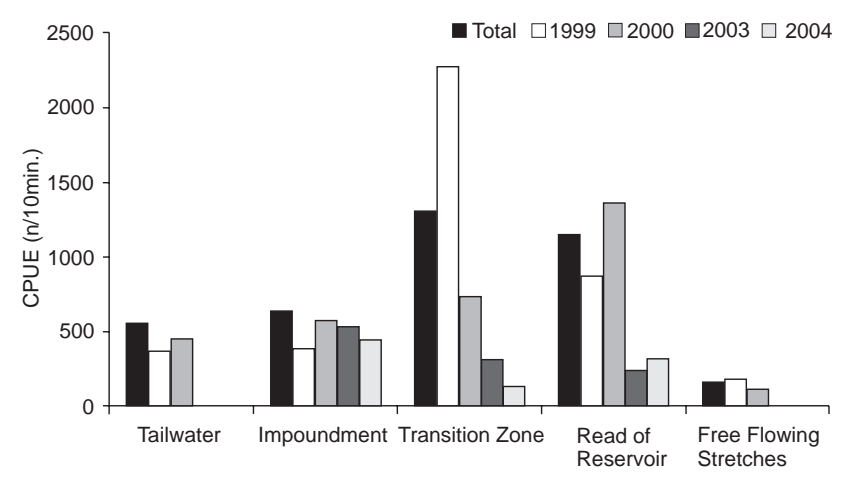

Figure 2. Fish frequency based on CPUE in each section of the investigation area.

After calculating the CPUE values of the guilds, the formation of the median confirmed a dominance of euryoecious species in the Impoundment and Transition Zone. The rheophilic and euryoecious species in Tailwater, Transition Zone and in the Free Flowing Stretches occurred in similar numbers. For the cluster analysis (Fig. 3) the pooled habitats were used as cases and the fish frequencies as variables. The cases are such that they enable the pooled habitats to be compared with the respective Danube mainstream section. The partial cluster 1 indicates connectivity between the habitats in the Impoundment, the Danube mainstream in the Impoundment and the habitats in the Transition Zone. A close relation is present between the Danube Transition Zone and the Danube Free Flowing Stretches in partial cluster 2. The third partial cluster demonstrates a connectivity between the habitats and the Danube mainstream in the Head of Reservoir as well the Tailwater.

The rankings (Tab. II) determine and illustrate the comparison of the frequencies of juvenile and adult fish. In Barbel, Barbus barbus (Linnaeus, 1758); Schraetzer, Gymnocephalus schraetser (Linnaeus, 1758); and Zingel, Zingel zingel (Linnaeus, 1766), clear divergences are evident.

\section{DISCUSSION}

Previous evaluation of the last years showed 62 species in the Austrian Danube (ZwEIMÜLler et al. 2000), where by 52 of those are autochthonous (SCHIEmer \& Waidbacher 1998). The Danube River is a migration pathway for Ponto-Caspian fauna as well as for neobiota from the Black Sea and therefore features a high biodiversity. In addition, some fish species, e.g. Danube Roach, Rutilus pigus virgo (Heckel, 1852); Zingel, Zingel zingel (Linnaeus 1766); or White Finned Gudgeon, Gobio albipinnatus Lukash, 1933 are endemic to the Danube river basin. Historical fish data show that the present fish spectrum corresponds to the original one for most of the Danube River (JUNGWIRTH 1975).

The power plant construction and the habitat changes have apparently affected the biocenosis. The migration was stopped for species like the Sterlet, Acipenser ruthenus Linnaeus, 1758. Others like the Common Minnow, Phoxinus phoxinus (Linnaeus, 1758), and Volga Zander, Sander volgensis (Gmelin, 1788) now find appropriate framework conditions for reproduction. Anadromous species, such as Acipenseridae (real sturgeons), have disappeared due to structural obstacles (e.g. dam "Iron Gate") and overfishing in the Austrian Danube (Jungwirth et al. 2003). This pertains especially to the Beluga, Huso huso (Linnaeus, 1758), and Ship Sturgeon, Acipenser nudiventris Lovetzk, 1828.

The reduced flow velocity, altered sedimentation and dominance of ripraps promoted the successful settlement of stable populations of stagnophilic and of alien species. The abundant fish in the Transition Zone and Head of Reservoir can be explained by the better framework conditions with respect to food supply and reproduction spaces. The abiotic factors create excellent conditions (varying flow velocities) and structural variety for the fish biocenosis.

An analysis of the fish species and guilds shows that euryoecious types dominate the spectrum. The Impoundment contains a wide range (39) of fish species. The reduced flow

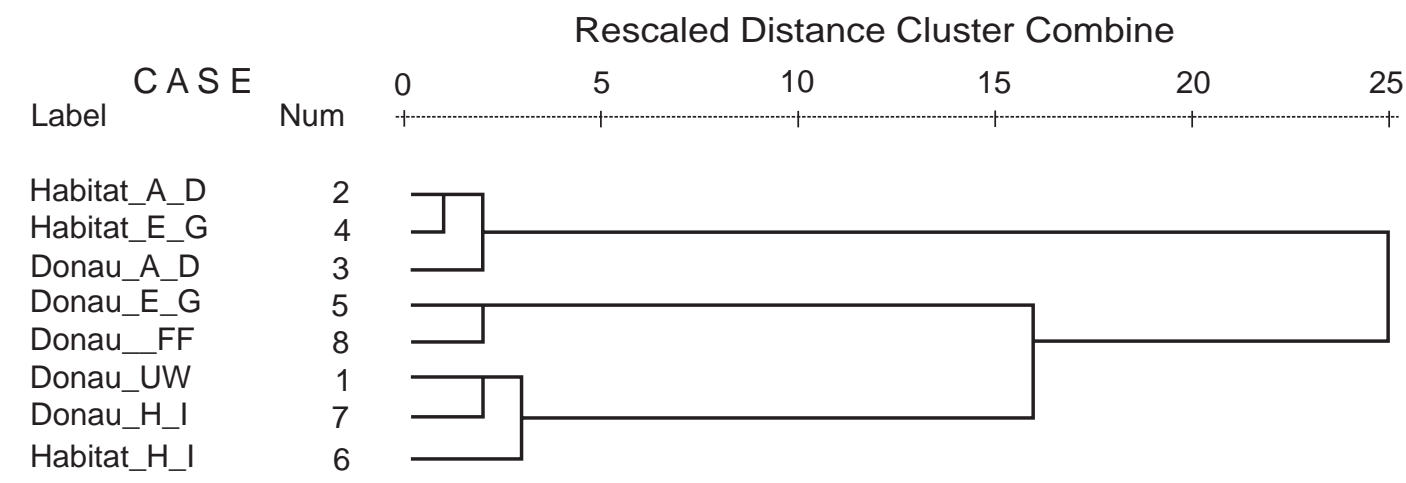

Figure 3. Cluster Analyses of the pooled habitats based on fish frequencies: Donau_UW refers to Tailwater; Donau_A_D refers to the Impoundment; Donau_E_G refers to Transition Zone; Donau_H_I refers to Head of Reservoir; Donau_FF refers to Free Flowing Stretches. 
Table II. Compared Mean Rankings of fish ages. Greater divergences are marked.

\begin{tabular}{|c|c|c|c|c|}
\hline \multirow{2}{*}{ Species } & \multirow{2}{*}{ Rheophilic grade } & \multicolumn{3}{|c|}{ Mean tanking } \\
\hline & & Total & Adults & Juveniles \\
\hline Anguilla anguilla (Linnaeus, 1758) & Stagnophilic & 15.1 & 16.3 & 17.3 \\
\hline Lota lota (Linnaeus, 1758) & Eurytopic & 35.2 & 35.1 & 36.7 \\
\hline Leuciscus cephalus (Linnaeus, 1758) & Rheophilic & 48.1 & 48.8 & 48.3 \\
\hline Salmo trutta forma fario Linnaeus, 1758 & Rheophilic & 24.5 & 29.1 & 15.5 \\
\hline Barbatula barbatula (Linnaeus, 1758) & Rheophilic & 12.9 & 15.7 & 15.5 \\
\hline Barbus barbus (Linnaeus, 1758) & Rheophilic & 37.8 & 13.9 & 41.1 \\
\hline Rhodeus sericeus (Pallas, 1776) & Stagnophilic & 23.6 & 23.9 & 27.9 \\
\hline Abramis brama (Linnaeus, 1758) & Eurytopic & 34.4 & 35.1 & 36.2 \\
\hline Gymnocephalus baloni Holcik \& Hensel, 1974 & Eurytopic & 24.6 & 27.8 & 20.1 \\
\hline Gasterosteus aculeatus Linnaeus, 1758 & Stagnophilic & 32.9 & 32.1 & 34.0 \\
\hline Perca fluviatilis Linnaeus, 1758 & Eurytopic & 47.4 & 48.1 & 45.1 \\
\hline Rutilus pigus (La Cepède, 1803) & Rheophilic & 26.6 & 22.1 & 25.7 \\
\hline Carassius gibelio (Bloch, 1782) & Eurytopic & 25.4 & 25.9 & 25.9 \\
\hline Carassius auratus (Linnaeus, 1758) & Eurytopic & 18.2 & 13.9 & 23.4 \\
\hline Ctenopharyngodon idella (Valenciennes, 1844) & Stagnophilic & 13.5 & 15.2 & 17.8 \\
\hline Gobio gobio (Linnaeus, 1758) & Rheophilic & 15.4 & 16.6 & 17.8 \\
\hline Blicca bjoerkna (Linnaeus, 1758) & Eurytopic & 38.1 & 31.5 & 38.3 \\
\hline Leuciscus leuciscus (Linnaeus, 1758) & Rheophilic & 43.1 & 34.5 & 45.3 \\
\hline Esox lucius Linnaeus, 1758 & Stagnophilic & 38.9 & 38.3 & 39.4 \\
\hline Hucho hucho (Linnaeus, 1758) & Rheophilic & 14.9 & 13.9 & 20.3 \\
\hline Carassius carassius (Linnaeus, 1758) & Stagnophilic & 13.9 & 13.9 & 18.9 \\
\hline Cyprinus carpio Linnaeus, 1758 & Eurytopic & 27.3 & 27.9 & 26.6 \\
\hline Neogobius syrman (Nordmann, 1840) & Rheophilic & 11.5 & 13.9 & 15.5 \\
\hline Gymnocephalus cernuus (Linnaeus, 1758) & Eurytopic & 20.2 & 18.4 & 25.6 \\
\hline Neogobius kessleri (Günther, 1861) & Rheophilic & 37.4 & 41.8 & 32.6 \\
\hline Gobio kessleri (Dybowski, 1862) & Rheophilic & 15 & 17.6 & 15.5 \\
\hline Cottus gobio Linnaeus, 1758 & Rheophilic & 40.8 & 44.3 & 31.7 \\
\hline Alburnus alburnus (Linnaeus, 1758) & Eurytopic & 51.5 & 51.9 & 50.5 \\
\hline Proterorhinus marmoratus (Pallas, 1814) & Eurytopic & 38.1 & 39.8 & 37.4 \\
\hline Chondrostoma nasus (Linnaeus, 1758) & Rheophilic & 48.4 & 46.1 & 48.4 \\
\hline Leuciscus idus (Linnaeus, 1758) & Rheophilic & 41.4 & 40.9 & 40.4 \\
\hline Oncorhynchus mykiss (Walbaum, 1792) & Rheophilic & 15.6 & 18.6 & 15.5 \\
\hline Rutilus rutilus (Linnaeus, 1758) & Eurytopic & 46.9 & 42.7 & 42.3 \\
\hline Scardinius erythrophthalmus (Linnaeus, 1758) & Stagnophilic & 22.5 & 26.4 & 20.3 \\
\hline Vimba vimba (Linnaeus, 1758) & Rheophilic & 26.5 & 21.3 & 30.6 \\
\hline Aspius aspius (Linnaeus, 1758) & Rheophilic & 41.3 & 37.6 & 38.6 \\
\hline Tinca tinca (Linnaeus, 1758) & Eurytopic & 20.9 & 23.8 & 20.7 \\
\hline Alburnoides bipunctatus (Bloch, 1782) & Rheophilic & 14.4 & 13.9 & 19.1 \\
\hline
\end{tabular}


Table II. Continued.

\begin{tabular}{|c|c|c|c|c|}
\hline \multirow{2}{*}{ Species } & \multirow{2}{*}{ Rheophilic grade } & \multicolumn{3}{|c|}{ Mean tanking } \\
\hline & & Total & Adults & Juveniles \\
\hline Gymnocephalus schraetser (Linnaeus, 1758) & Rheophilic & 32.9 & 36.9 & 15.5 \\
\hline Pelecus cultratus (Linnaeus, 1758) & Rheophilic & 17.5 & 16.3 & 19.8 \\
\hline Lepomis gibbosus (Linnaeus, 1758) & Stagnophilic & 16.3 & 19.8 & 15.5 \\
\hline Cobitis taenia Linnaeus, 1758 & Rheophilic & 21.9 & 25.4 & 15.5 \\
\hline Zingel streber (Siebold, 1863) & Rheophilic & 16.3 & 18.8 & 17.1 \\
\hline Gobio albipinnatus Lukash, 1933 & Rheophilic & 25.7 & 26.8 & 22.2 \\
\hline Silurus glanis Linnaeus, 1758 & Eurytopic & 14.4 & 16.6 & 18.6 \\
\hline Sander lucioperca (Linnaeus, 1758) & Eurytopic & 36.7 & 33.2 & 37.0 \\
\hline Zingel zingel (Linnaeus, 1766) & Rheophilic & 27.9 & 31.1 & 15.5 \\
\hline Abramis sapa (Pallas, 1814) & Rheophilic & 14.1 & 16.6 & 15.5 \\
\hline Abramis ballerus (Linnaeus, 1758) & Rheophilic & 11.5 & 13.9 & 15.5 \\
\hline Ameiurus nebulosus (Lesueur, 1819) & Stagnophilic & 13.4 & 16.3 & 15.5 \\
\hline Barbus peloponnesius Valenciennes, 1842 & Rheophilic & 13.5 & 13.9 & 18.0 \\
\hline Neogobius melanostomus (Pallas, 1814) & Rheophilic & 11.5 & 13.9 & 15.5 \\
\hline
\end{tabular}

velocity after the power plant construction shifted the rheophilic ichthyofauna to a stagnophilic and euryoecious guild membership.

Currently, 33 of the 52 recorded species at the study site are found in the immediate Tailwater (without riparian forest). This may also reflect reduced predator pressure as well as compensation and spawn migration. The fewest species were found in the Free Flowing Stretches; they mainly represent rheophilic forms.

In principle, stagnophilic-euryoecious species dominate the Impoundment and the Transition Zone. The Head of Reservoir and the Free Flowing Stretches are preferred by rheophilic fish.

This study confirmed the acceptance of habitats by fish species. The statistical analyses, such as the cluster analyses with pooled habitats, demonstrated connectivity between the habitats and the Danube mainstream. The partial cluster 1 (Fig. 3) can be summarized by flow velocity and includes stagnophilic and euryoecious species. The connection in partial cluster 2 can be explained by migration of rheophilic species to the Transition Zone. The factors food, reproduction and flow velocity equally explain the third partial cluster.

At the present time the anthropogenically created habitats represent good replacements. Nevertheless, these habitats will never have the full quality of a natural, persistent aquatic ecosystem. This explains the great difference compared with the original spectrum of fish species, despite the high acceptance and functionality.

The construction of hydropower plants drastically changes the natural structure and in consequence impairs the fauna, flora and the hydrologic conditions. Anthropogenically created habitats are limited substitutes for natural environments. This calls for further examinations and a monitoring program to better describe and understand this aquatic ecosystem.

\section{ACKNOWLEDGEMENTS}

To the initiators: European Union (EFRE), Water Management magistrate of Vienna (MA 45), Austrian Federal Ministry of Science and Research, Office of Lower Austrian Government (NÖ Landschaftsfonds) and VERBUND Austrian Hydro Power. To all dear colleagues from the Institute of Hydrobiology and Aquatic Ecosystem Management, BOKU Vienna for the data sources and for support in the analyses; to E. Lautsch for special database instruction in the statistical analysis software; to F. Stauffer for suggestions on the manuscript.

\section{LITERATURE CITED}

Admicka, P.; G. Bretschko; E. Danecker; J. Hinteregger; G. Imho;; M. Jungwirth; M. Leichtfried; O. Moog; C. Moritz; G. Müller; R. Pechlaner; E. Pipp; E. Polzer \& N. Schulz. 1992. Zur Gewährleistung, Beeinträchtigung und Beurteilung der ökologischen Funktionsfähigkeit von Gewässern. Österreichs Fischerei 45: 120-121.

Cowx, I.G. \& P. Lamarque. 1990. Fishing with Electricity. Fishing New Books. Oxford, 248p.

GiNZLER, B. 2002. Fischökologische und morphologische Verhältnisse im Einflussbereich des Kraftwerks Wien/ 
Freudenau unter besonderer Berücksichtigung der neu geschaffenen Uferstrukturen am linken Donauufer im Bereich der Donauinsel. Wien, Universität für Bodenkultur, 149 p.

JungwirTh, M. 1975. Die Fischerei in Niederösterreich. Wissenschaftliche Schriftreihe St. Pölten/Wien, Niederösterreich. NÖ Pressehaus, 31p.

Jungwirth, M.; G. Haidvogl; O. Moog; S. Muhar \& S. Schmutz. 2003. Angewandte Fischökologie an Fließgewässern. Wien, Facultas Universitätsverlag, 547p.

Schiemer, F. \& H. Waidbacher. 1998. Zur Ökologie großer Fließgewässer am Bespiel der Fischfauna an der österreichischen Donau. Stapfia 52, zugleich Katalog des OÖ Landesmuseums N. F. 126, p. 7-22.

Schmutz, S.; M. Kaufmann; B. Vogel \& M. Jungwirth. 2000. Methodische Grundlage und Beispiele zur Bewertung der fischökologischen Funktionsfähigkeit österreichischer Fließgewässer. Wien, Wasserwirtschaftskataster des BMFUW, 210p.

SPSS. 2007. SPSS 16.0 für Windows. Version 16.0.1 [7.XII.2007], Copyright SPSS Inc.

Waidbacher, H.; G. Haidvogl \& R. Wimmer. 1996. Beschreibung der räumlichen und zeitlichen Verteilung der benthischen Lebensgemeinschaften und der Fischbiozönosen im Projektbereich des KW Freudenau (Limnologische Beweissicherung). Wien, Institut für Hydrobiologe und Gewässermanagement der Universität für Bodenkultur, 184p.

Zweimüller, I.; S. Guttmann; G. Singer; E-M. Schober \& A. Weissenbacher. 2000. Eine neue Fischart für Österreich Neogobius syrman (Normann, 1940). Österreichs Fischerei 53: 186-189.

Submitted: 30.VI.2009; Accepted: 18.II.2010.

Editorial responsibility: Kleber Del Claro 